\title{
Capacity, claims and children's rights
}

\author{
Mhairi Cowden \\ Research School of Social Sciences, Australian National University, ACT 0200, Australia. \\ mhairi.cowden@anu.edu.au
}

\begin{abstract}
Children are often denied rights on the basis of their incompetence. A theory of rights for children is essential for consideration of the child's political status, yet the debate surrounding children's rights has been characterised by the divisive concept of 'capacity' typified in the two leading rights theory, Interest Theory and Will Theory. This article will provide a thorough analysis of the relationship between capacity, competence and rights. Although Interest Theory has successfully dealt with the competence requirement for being a right-holder, the competence requirement still holds for the type of rights a child holds. Children's interests are determined sufficiently strong to found a right when the claim-holder has the competence to realise the benefit to which that interest pertains. This allows us to recognise children as right-holders while constraining the types of rights they hold according to their developing competencies.

Contemporary Political Theory (2012) 11, 362-380. doi:10.1057/cpt.2011.43;

published online 17 January 2012
\end{abstract}

Keywords: children; rights; W.N. Hohfeld; capacity; competence

We often assume that it is correct to deny children rights by reference to their lack of capacity. For example the debate about lowering the voting age in Australia is dominated by claims that those younger than 18 lack the capacity to understand the complex political system. ${ }^{1}$ We find it acceptable that there is a fixed age in law below which one is incapable of consenting to sex, driving a car or incompetent to stand trial. Many of us laugh at cartoons in the media depicting children asking their lawyers to negotiate higher levels of pocket money (Fortin, 2003, p. 10). But why? It seems that a child's lack of capacity sets her apart from adults in such a way that the systematic denial of rights is entirely appropriate. If this is true then it is important to locate the basis of this capacity argument within rights theory.

Locating the correct relevance of capacity (or more correctly, incapacity) within rights theory will help to shed light on the nature of children's rights.

(C) 2012 Macmillan Publishers Ltd. 1470-8914 Contemporary Political Theory Vol. 11, 4, 362-380 www.palgrave-journals.com/cpt/ 
Many will be surprised to learn that although much of our contemporary political discourse is dominated by the concept of rights, there still exists a largely unresolved debate over whether children actually have them. ${ }^{2}$ This may not be as surprising to others who have observed the traditional neglect of children throughout moral and political philosophy. ${ }^{3}$ Exploring the relationship between capacity and rights is part of the broader project of rectifying this neglect.

This article will offer an explanation of the proper relationship between rights and capacity and how this affects children as right-holders. After setting up a broad definition of children and childhood I will identify the 'argument from incompetence', which seeks to deny or restrict children's rights by reference to their incapacity. I will then introduce some conceptual distinctions between capacity, competence and ableness, arguing that we need such clarity to properly understand the relationship between these concepts and rights theory.

The second part of the article will examine the two leading theories of rights - will theory and interest theory. In will theory children are denied the status of right-holder owing to a focus on their incapacities whereas interest theory's shift from 'self-determination' to the protection of interests does not account for the limitations a child's developing capacities present. This article employs Hohfeld's analytical rights framework to determine how a child's capacity for enforcement and realisation influences the different concepts that may constitute a right and concludes that the Hohfeldian incident of power is the most relevant for the question of capacity.

Finally I will argue that while competence may not be necessary for the enforcement/waiver of a right, it is necessary for the realisation of a right. Competence plays an integral role in interest theory, one that is fundamental to understanding the structure of children's rights. Rights are constrained by the competence of the claim-holder and the importance of their interest to impose upon others' Hohfeldian liberties. Conceiving of rights in this way will provide us with the building blocks with which to begin more complicated theoretical conversations concerning the position of children within moral and political theory.

\section{Concepts and Definitions}

As Brocklehurst points out, there is 'no single or agreed definition of childhood recognised or acted upon worldwide (2006, p. 1). The concept of childhood is used to identify everyone from newborn babies to young adolescents, and the meaning of the term differs greatly across history and cultural traditions (Aries, 1962). The diverse nature and significance of childhood presents deep challenges for anyone wishing to bring analytical rigour to the subject.

C) 2012 Macmillan Publishers Ltd. 1470-8914 Contemporary Political Theory Vol. 11, 4, 362-380 363 
Article One of the United Nations Convention on the Rights of the Child (UNCRC) defines children as 'every human being below the age of eighteen unless under the law applicable to the child, majority is attained earlier' (UNCRC, Article 1). Much has been said about the arbitrary nature of any age-related definition of children (Archard, 2004, p. 85). Given the gradual and variable nature of human development any fixed age will be open to the challenge that some individuals are physically and cognitively adult long before they are recognised so by the state. Lowering the age from 18, however, would similarly draw criticism that some 16-year-olds are not yet mature enough to be considered adults. There will always be outliers in any age-related definition of childhood.

Despite the difficulty of age-related definitions, one thing is certain, the concept of childhood cannot be understood unless we have a concept of adulthood. A child is defined as one who is not yet adult. If being adult is when one is in full control of one's factual capacities then childhood can be generally understood as a period of reduced physical and cognitive capacities coupled with a rapid development of these capacities. It is a time when one goes from total dependence as a baby to relative independence as an adult. As Archard states, 'the underdevelopment of children is a biological given, a brute fact of human existence' $(2004$, p. 25). However, the concept of childhood is not entirely biological but is also socially constructed. The way in which we understand and attach meaning to these 'biological givens' is created by the society we live in. Therefore the significance attributed to this period of cognitive, moral and physical development has differed greatly across history and continues to differ across cultures today (Veerman, 1992; Brocklehurst, 2006, p. 1).

While recognising the differing significance of childhood, I will take childhood simply to mean the period of time before one becomes an adult, usually defined by lesser physical and cognitive capacities coupled with the rapid development of these capacities. This definition is intentionally broad and does not seek to identify an age by which one ceases to be a child. The vast difference in capacities between a 2-year-old child and a 14-year-old child, the development and evolution of children's capacities, is what any theory of rights must account for. It must explain how to recognise children as right-holders despite their differing capacities yet also taking account of the importance of these capacities. The approach that I propose throughout blurs the line between child and adult. I shall argue that rights are contingent on an individual's interests and ability to realise the benefit of the interest, and therefore the distinction between child and adult becomes largely unimportant for right theory.

The most common argument employed when denying children of any age the rights afforded to adults is that they have reduced physical and cognitive

364 (C) 2012 Macmillan Publishers Ltd. 1470-8914 Contemporary Political Theory Vol. 11, 4, 362-380 
capacities. For simplicity I will refer to this as the argument from incompetence. The argument from incompetence generally can be described as thus:

To hold a right one must have certain capacities, such as the capacity to feel pain, make choices or to think rationally. Children are in a state of developing those capacities and acquiring competency and therefore cannot hold the rights, unlike adults whose physical and cognitive competencies are fully developed.

The argument from incompetence can be seen throughout traditional liberal philosophy. Hobbes regarded children as lacking the capacity to enter into the social contract because of their inability to reason (1985), Locke argued that children were in a temporary state of inequality because of their irrationality (2004, p. 306) and John Stuart Mill stated with regard to his political theory that it was 'hardly necessary to say ... we are not speaking of children' (1992, pp. 13-14).

A version of the argument from incompetence pervades one of the leading theories of rights - the will or choice theory, hereafter referred to as will theory (Hart, 1955; Wellman, 1995; Steiner, 1998). Will theory claims that children cannot be right bearers because they lack the capacity to make rational choices. It is widely recognised by developmental psychologists that children are not born with the capacity to make rational choices, and that this is a capacity that they develop (Piaget, 2004). Therefore the argument from incompetence, as espoused by will theorists, seems to be fatal for understanding children as rights bearers. Recent literature on the rights of children has focused on 'autonomy' rights - those rights that involve the uncoerced choices and actions of the right-holder according to their conception of the good life (Brennan, 2002; Brighouse, 2002). Brighouse argues that it is not sensible to ascribe agency rights to children (2002). Griffin, too, in an extension of his definition of human rights, has argued that infants do not have rights by virtue of their lack of the capacity for agency (2002).

If such significance is placed on a child's lack of capacity - with implications for their moral and political status - then it seems necessary to locate the exact way in which capacity, or the lack of it, is important to rights theory. To do this I will employ a Hohfeldian framework to examine how exactly capacity is relevant to will theory. I will then examine the rival alternative, interest theory, and argue that even though interest theory makes it conceptually possible for children to be right-holders, it has not completely overcome the argument from incompetence.

Before examining each theory of right it is useful to introduce some conceptual clarifications. Although the definition of childhood is sufficiently 
broad for our purposes, our understanding of capacities must be further refined. So far throughout this article I have been using the term capacity in its broadest sense, encompassing both capacity and competence. Although the terms capacity and competence are often used interchangeably throughout the children rights literature there are important conceptual differences between the two. Any consideration of capacity is best understood through a breakdown of the definitions of capacity, competence and ableness. ${ }^{4}$

Capacity can be understood as one's counterfactual ability, and competence as one's actual ability. This distinction between capacity and competence can be seen through the simple example of the student and the turtle. Neither the turtle nor the student is currently capable of speaking Russian; however, while the student can take Russian lessons and will one day be able to speak the language, the turtle will never be able to, no matter how many lessons he takes. In this way both the turtle and the student currently lack the competence to speak Russian; however, the student has the capacity to one day be competent (Cowden and Lau, 2011). A further layer can be added through the concept of ableness (Morriss, 2002, p. 80). Ableness is one's specific competence plus opportunity, for example I may have the competence to get married, but I cannot do so because I have no one to marry. In this sense I am not able. Ableness encompasses the external resources and opportunities one needs to complete an act (Dowding, 2006, p. 325). The relationship between the three concepts can be seen below Figure 1 .

This raises an important moral distinction between children and other groups of incompetents such as animals. Although a young baby and a puppy may both currently be incompetent, a young child will develop the competencies to one day make complex moral decisions while the puppy will not.

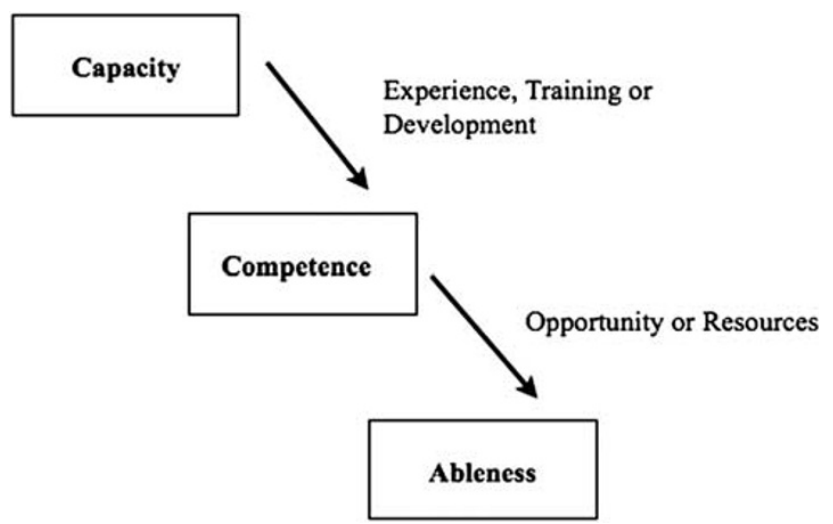

Figure 1: The relationship between capacity, competence and ableness 
As we will see will theory places both children and animals in the same category; however, a proper understanding of the distinction between capacity and competence shows that there is a distinction. This distinction, I believe, is sufficient to warrant acknowledgement in any theory of rights. It is relevant therefore to ask whether the denial of rights is based on one's actual competence or one's capacity.

\section{Theories and Functions of Rights}

All assertions of rights can be understood in terms of four basic elements, the Hohfeldian incidents (Wenar, 2005, p. 2). Hohfeld's framework of rights is an exercise in analytical jurisprudence and logical reasoning, separate from the contentious disagreement surrounding the normative force of rights. The Hohfeldian framework can therefore provide us with the necessary tools in order to engage in a clear, reasoned argument regarding the proper function of rights.

The Hohfeldian rights framework unpacks the internal structure of a 'right' into eight incidents: claim, duty, liberty, no claim, power, liability, immunity and disability. The relationship between these can be seen below Figure 2 .

$\mathrm{A} / \mathrm{B}$ can be understood as 'When there is A, there is no B'

$\mathrm{A}-\mathrm{B}$ can be understood as 'When there is A, there is B'

By briefly examining the four prominent Hohfeldian incidents - claim, liberty, power and immunity - we can begin to pinpoint the exact issue capacity or competence poses for a child's right.

In Hohfeldian terms, $A$ has a claim that $B$ do $\alpha$ if and only if $B$ has a duty to $A$ to $d o \alpha$. The Hohfeldian framework stipulates that a claim always has a correlative duty specified by reference to the actions of the object that bears the correlative duty. A's claim creates a duty in B to (1) abstain from interference or (2) render assistance or remuneration (Wenar, 2005, p. 7). I have a claim to

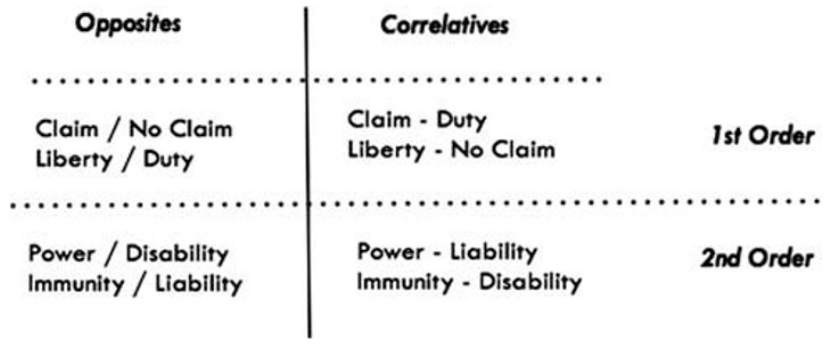

Figure 2: The Hohfeldian rights framework 
my life and therefore you have a duty not to kill me. As a claim is always defined by the actions of the duty bearer, neither capacity nor competency on the part of the claim-holder is relevant to their status within Hohfeld's framework. A child's incapacity or lack of competence does not prevent them from being a claim-holder.

Within Hohfeld's framework $A$ has a liberty to do $\alpha$ if and only if $A$ has no duty not to do $\alpha$. A liberty is specified by reference to the actions of, A, the liberty-holder. For example my liberty to ride my bike is my freedom from any duty to refrain from riding my bike. A liberty is not dependent on the libertyholder's actual competence or capacity to exercise the liberty even though it is defined by the actions of the liberty-holder (Sumner, 1987). For example, if I break my leg and am bound to bedrest, I am still at liberty to walk down the street, even though I am currently unable to exercise this liberty. In this way a liberty is not concerned with the liberty-holder's competence or capacity. If this holds true, then a child's developing capacities and competencies do not preclude them from holding a liberty. A baby holds a liberty to walk down the street before it has developed the actual competence to do so.

A power consists in one's ability to effect changes in other's or one's own claims and duties (Sumner, 1987). I have a power to enforce my claim to exclusive possession by removing a squatter from my land; I also have the power to waive my claim to exclusive possession to allow him to stay. Therefore: $A$ has power if and only if $A$ has the ability to alter her own or another's Hohfeldian incidents.

Powers like Liberties are specified in reference to the actions of the holder. However, unlike a liberty, in order to hold a power, one must be factually competent (Sumner, 1987; Kramer, 1998). There is a difference between factual and legal competence as one can be factually competent in an act but not be legally authorised (Kramer, 1998, p. 69). For example one may be legally authorised to drive a car, but be temporarily factually incompetent to do so due to a broken arm. Therefore for a child to hold a power we must consider their competence. We are not concerned with one's counterfactual capacity to alter one's own or another's Hohfeldian incidents but with one's actual competence. For example, if I am in a coma I may have the capacity to speak and make decisions regarding my life and property but currently lack the competence to do so. This incompetence means I lack the power to waive my rights.

The necessity of factual competency poses a problem for children because they are, at any given time, at different stages of gaining both physical and cognitive competency. Therefore at varying points of their development they may not have the factual competency required to hold a power.

One has immunity when one is shielded from another's power. A landowner's immunity prevents the government from compulsorily acquiring

368 (C) 2012 Macmillan Publishers Ltd. 1470-8914 Contemporary Political Theory Vol. 11, 4, 362-380 
their land without just compensation. Therefore: $A$ has an immunity if and only if $B$ lacks the ability to alter A's Hohfeldian incidents. As an immunity relates to one's protection from the exercise of another's power, not to the immunity holder's capacity or competence, therefore a child would seem to be equally capable of holding an immunity as an adult.

The Hohfeldian framework demonstrates that when we consider the essential building blocks of rights, it is the incident of power that is of most concern for children as right-holders. For the majority of Hohfeldian incidents - claim, liberty and immunity - a child's developing capacities and competencies pose no problem. We can also observe that it is competence, one's actual ability to do the act, and not capacity, that is necessary for a child to hold a power. Having identified that it is the Hohfeldian incident of power that is relevant to competence we can now examine what part power has to play in the two competing understandings of the function of rights, will theory and interest theory.

Will theory understands rights as normative allocations of freedom; they demarcate domains or spheres of practical choice where individuals are not subject to interference (Steiner, 1998, p. 238). Thus a right makes the rightholder a 'small scale sovereign' (Hart, 1982, p. 183). The function of the right is to give its holder power over another's duty. Therefore a will theory right $=$ Hohfeldian claim + Hohfeldian power The Hohfeldian rights framework tells us that one must have factual competence in order to hold a power. Therefore for a child to be able to hold a will theory right they must be factually competent of the rational choice to enforce or waive one's right (Kramer, 1998, p. 69).

It is this emphasis on factual competency and the necessity of the inclusion of power within a will theorist's definition of a right that is fatal for children's rights. Studies show that very young children do not have the competence to distinguish between self and others; it is clear that without such a competence a very young child would be incapable of making the decisions relating to the enforcement or waiver of their claims, ${ }^{5}$ because to make such a decision would necessarily involve the ability to conceive of interpersonal concepts such as 'claim' (Piaget, 2004; Lansdown, 2005, p. xiii).

Will theorists have famously had little problem boldly grasping this nettle. As children, particularly infants and young children, are incompetent to engage in enforcement and waiver decisions, they cannot hold the enforcement/waiver powers and therefore cannot hold rights (Hart, 1955). The distinctive feature of children's rights in will theory seems to be that they do not exist (Campbell, 1992, p. 2).

Will theory's emphasis on choice has a 'confining effect' on the articulation of children's rights that cannot be avoided (Federle, 1994, p. 348). Children's state of evolving capacities means that according to will theory they fall into 
the same category as all other non right-holders, such as the mentally incapacitated, animals or inanimate objects. Will theory therefore is unable to distinguish between children and other incapacitated groups; it fails to recognise that although children may not currently have the requisite competency, they do hold capacities - a point that seems to distinguish them from those individuals who are static in their incompetence. It is owing to these difficulties that many reject will theory as an appropriate theory to properly define how we wish to use rights.

Interest theory holds that the function of a right is to further a right-holder's interests. Instead of constraining the function of rights to the protection of an agent's choice or free will, interest theory seeks to encompass a wider domain. Interest theorists argue that a right's function is to protect those things, goods and services that are so intrinsically important to us that they are in our interest. Those people who may lack the power to obtain these goods for themselves, who lack competencies, are often those that need the protective force of rights the most.

In this way Kramer defines rights as 'modes of protection for interests that are treated as worthy of protection', and Raz states that ' $x$ has a right if ... an aspect of x's well-being (his interest) is a sufficient reason for holding some other person(s) to be under a duty' (Raz, 1984, p. 195; Kramer, 1998, p. 79). Therefore an interest theory right $=$ Hohfeldian claim that protects an interest worthy of protection.

An interest deemed worthy of protection is one of sufficient importance to impose a duty on another person. An interest is of sufficient importance when it will benefit the claim-holder. However, the most important distinction between will theory and interest theory is that a claim protecting an interest does not need to be combined with the power to waive or enforce this claim. The power can theoretically lie outside of the claim-holder without damaging the conceptual coherence of the claim. A's competency to demand or waive the enforcement of a right is neither sufficient nor necessary for A to be endowed with that right (Kramer, 1998, p. 62). For example, consider the fact that I am in a coma because I have suffered a violent and unprovoked beating. I am not able to go to the courts and seek remedy for my attack, as I am unconscious. However, just because I am temporarily powerless to enforce my claim to be free from physical assault does not mean that I have lost the claim altogether. In fact in this situation it may be appropriate that in the absence of my competency someone else will enforce the claim on my behalf. In recognising that the power to enforce or waive a claim can lie outside the claim-holder, we can acknowledge that this power can lie with the state or a designated institution or individual.

The separation between claim and power logically allows for the fact that a child lacking the competency to hold a power is not excluded from holding an 
interest theory right. As observed in the previous analysis, there is no competence-related impediment involved with a child holding a Hohfeldian claim, as these claims are defined by reference to the actions of the duty bearer. Therefore children are capable of holding rights if we understand rights as Hohfeldian claims held by an individual that pertain to a duty to either do or refrain from doing a particular action. The power to enforce this claim can be held by the right-holder or another designated entity. This claim constitutes a right when it is based on an interest of sufficient importance to impose duties on others.

From here the conclusion drawn by interest theorists is that by shifting the focus of rights to interests the argument from incompetence is overcome. Children can now hold rights unconstrained by concerns regarding competence or capacity (MacCormick, 1976; Campbell, 1992; Kramer, 1998). Campbell concludes that a child's lack of development does not pose a problem for children holding rights. He argues that lack of development is really just a 'superficial point of theory'; the incapacities of the child and the implications this has for protecting a right are really a political question (Campbell, 1992, p. 12). Federle, too, despite her belief in its inadequacies, claims that in this regard, the interest theory appears most promising to children's rights theorists because it proposes to resolve the problem of having a right without the present ability to exercise it' (Federle, 1994, 352).

I argue, however, that interest theory has not accomplished this. A proper understanding of the relationship between competence and interest theory demonstrates that a child cannot hold a right without the present ability to exercise it. A child's developing capacities and competencies are not just a superficial point of theory. The next section of this article will argue that although interest theory may have shown that competence is unnecessary to qualify as the type of thing that could hold a right, it may still be necessary to realise a particular right.

\section{Realising Rights and Imposing Duties}

To hold an interest theory right one must have interests. There is much debate about whether other beings, such as animals, have interests and therefore rights. However, I do not seek to enter into this argument here. I take an interest simply to mean something that is presumptively beneficial to the claimholder (Raz, 1984, p. 205). The thin evaluative stance of interest theory assumes the basic distinction between beneficial and detrimental (Kramer, 1998, p. 93). This is not to say that the boundaries of what constitutes a presumptively beneficial interest are not controversial; there will always be (and rightly so) debate regarding the edges of what is beneficial. However, 
a controversial fringe does not logically preclude that such beneficial interests do exist. Most importantly it seems relatively uncontroversial that children have interests that are of intrinsic benefit to them, such as a baby's interest in receiving adequate nutrition. If we accept that children are beings that have interests then a child (so far) can hold an interest theory right.

From this first step the clearest way to identify the role competence plays in interest theory is by examining the different ways in which a right comes not to be fulfilled. Disregarding the intentional choice of the duty-holder to breach their duty or the choice of the right-holder to waive a duty, why would a right not be fulfilled? I identify three situations where this may be the case.

A right cannot be fulfilled when the external environment precludes either the right-holder or duty-bearer from fulfilling their duty or exercising their right, respectively. For example, a government may wish to fulfill its duty to provide young children with adequate food and nutrition; however, the country suffers a debilitating drought. Although the government wishes to fulfil its duty, it is prevented from doing so.

A right cannot be fulfilled when the duty-holder does not have the competence to fulfil the duty. For example we may state that children have a right to be loved by their parents, yet a mother who suffers from severe postnatal depression may be incapable of loving her child (Cowden, 2011).

A right cannot be fulfilled when the right-holder does not have the competence to realise it. For example the claim that one has a right to work may produce a duty in the state to assist those who are unemployed to find employment. This would not hold for a new born baby who lacks the competence to work at a job.

Do any or all of these extinguish the existence of the right, or do they simply point to its abrogation? The first situation, that of the drought-stricken country, benefits from consideration of the concept of ableness set out at the beginning of this article. Ableness encompasses two parts - competence plus external resources. The government of the country may have the competence to deliver food to its child citizenry, as it has a functioning agricultural industry and a bureaucracy for effective distribution. However, the existence of a drought deprives the government of the external resources and opportunity to do so. This situation presents a complicated and important question for those concerned with the implementation of rights. However, as it is about external circumstances and does not address the issue currently at hand, that of the claim-holder's competence, I will not consider it further. I will focus on the second and third situations. We will first examine the relevance of a claim-holder's competence to realise a right, and then consider how this can create duty-holders who are incapable of fulfilling their duty. I argue that interest theory necessitates that the right-holder have 
the competence to realise the right in order for the interest to be of sufficient importance to impose duties and restrict the liberties of others.

As we saw above, the claim-holder is able to realise the content of their claim when they have both the competency, as in the actual ability, and the ableness, as in the external resources and opportunity, to do so. By putting aside the necessity of external resources we have singled out the requirement of competence.

The competence required to realise a claim is distinct from the previously discussed competence required to hold the power to waive or enforce that claim. For example, I realise my claim to vote when I fill out the ballot paper. I enforce my claim to vote, however, when someone breaches their duty to allow me to vote and I take them to court. I waive my right to vote when I decide not to attend the polling booth. If the state legislates against me voting, I have lost my power to enforce or waive my claim, but not my competence to realise it. Therefore the competence relating to the power to enforce or waive one's claims can be unrelated to the competence required to realise one's claim. The second part of this article demonstrated that interest theory allows the power to enforce a claim to reside outside the claim-holder; therefore the competency to enforce or to waive is no longer necessary to hold a right. What interest theorists have not done is to demonstrate that the competence to realise the claim is also unnecessary. ${ }^{6}$

When the claim-holder does not have the competence to realise the content of their claim, the claim is unfulfilled. The reason for this lies at the core of what it means to protect an interest - that it is presumptively beneficial to the claim-holder. From this, it follows that if a child does not have the competence to realise the benefit to which the claim pertains, the interest may not qualify as of sufficient importance to be protected. To illustrate this we can consider whether a blind man has a right to illumination. A blind man can have no interest in the lights being on so he can read the newspaper, whereas an ablesighted person may do. If we consider the thin evaluative stance of presumptively beneficial, the presence or absence of light can have neither benefit nor detriment to someone who cannot detect it. As the blind man cannot see, he cannot realise the benefit of the light, and therefore can have no interest on which to ground a claim. Without the relevant competence he has no right to illumination. ${ }^{7}$

Consider an alternative example: assume I have a deep and intense interest in flying without the assistance of external mechanisms; it is of constant concern to me, and it occupies my thoughts day and night. The fulfillment of this would greatly enhance my intrinsic well-being. Flying without assistance seems at first glance to be presumptively beneficial. I also assert that this claim produces a positive duty in others to help me to realise it. However, we know 
that it is impossible for me to fly without assistance, because I lack not only the competence to currently achieve it but also the underlying capacities to ever be able to do so in the future. Furthermore, unlike the example of the blind man, to impose a duty on others to help me achieve my interest in flying is to impose a duty on others that they can never fulfill, a situation I will return to below. It therefore seems that the competence of the claim-holder to realise the claim is extremely relevant to whether or not it constitutes a right. To return to our original example, a newborn cannot hold a right to gainful employment, because they lack the competence to work at a job and therefore cannot realise the benefit to which their claim pertains.

The impossibility of fulfilling one's duty leads us to the second important feature of an Interest theory right. According to interest theory, rights ground requirements for action in other people (Raz, 1984, p. 208). An interest, therefore, must be of sufficient importance to impose a duty on someone else. If we are protecting the right-holder's interests by imposing normative constraints on other people's Hohfeldian liberties, then these actions of constraint must be justified (MacCormick, 1976). The constraints must be reasonable and achievable. It is not just the competence of the claim-holder that is relevant but also the cost of fulfilling the duty imposed on the duty-holder.

Let us consider again the blind man's prospective right to illumination. Although the blind man lacks the competence to realise the benefit of the right, the correlative duty would still be possible to comply with. In other words the potential duty is still achievable - for example, if we considered the blind man's interest as worthy, we could dictate that we must turn the light on for him and enforce this duty. Now consider two people in a room, an able-sighted person who wishes to go to sleep and the blind man who wishes to keep the light on. The sleeper's liberty to sleep in the dark would be constrained by their duty to keep the light on. The cost of the duty, in depriving the able-sighted person of their liberty to sleep in the dark, seems to outweigh the negligible benefits the blind man could derive from illumination. Therefore, the assessment that the blind man's interest in illumination is not of sufficient importance to impose a duty rests not only on the blind man's lack of competence to realise the interest, but also on the disproportionate costs imposed on the potential duty-holder's liberties.

Determining whether one holds a right under interest theory is therefore a balance between (a) the claim-holder's interest, (b) the claim-holder's competence, and (c) the cost to others of bearing the duty. This relationship can be examined by further breaking down the types of claims. All claims are passive as they require action or inaction on the part of the duty-holder, not the claim-holder. Claims can broadly be seen to fall into four categories, those claims that produce a duty of non-interference (N1 and N2) and those claims 
that produce a duty to provide goods or services (P1 and P2). All of these claims necessitate competence within the claim-holder.

N1: Claims producing duties of noninterference protecting the actions of the claim-holder.

These are claims of noninterference from others to protect the action of the claim-holder, for example, I have a claim to walk down the street without someone preventing me. For this to be a claim based on an interest of sufficient importance, the claim-holder must have the competence to realise the claim. If I am temporarily incompetent and cannot walk down the street because I have broken my leg, I am still at liberty to do so, but my lack of competence means it is of insufficient importance to impose a duty on others, as I will not be able to realise the benefit to which the claim pertains.

N2: Claims producing duties of noninterference protecting the state of being of the claim-holder.

These claims do not protect actions by the claim-holder, but instead protect the claim-holder's state of being, for example, the right not to be tortured. We do not decide whether to feel pain or not; rather it is something that refers intrinsically to the state of being of the agent. However, a claim-holder must be competent of feeling pain. For example, if I cannot feel pain, I do not suffer if someone pokes me with a needle repeatedly. I may have a claim against this person for other reasons, such as violation of my bodily integrity, but it cannot be based on a right to be free from pain.

P1: Claims producing duties of action to enable actions of the claimholder.

These are claims of assistance in enabling the claim-holder's actions. For example, a child's claim against the state to receive adequate education in order to vote; or, in the hypothetical case above, my right for others to enable me to fly. Much like N1, a claim-holder must have the competence to realise these claims or else they impose duties that can never be fulfilled. They become unreasonable constraints on the Hohfeldian liberties of others.

P2: Claims producing duties of action that protect the state of being of the claim-holder. 
These claims protect the claim-holder's state of being but still require a level of competency. Consider a child's claim to be provided with adequate healthcare or to clean water. The child must be competent of deriving benefit, and the water is of intrinsic benefit to the child, because they have the competency to use it to extract nutrients and convert them into energy.

In this broad classification all four types of claims necessitate a certain level of competency on the part of the claim-holder. In situations N1, N2 and P2, a duty-holder can still fulfill the duty imposed on them even if the right-holder is not competent of realising the right. However, in each situation the imposition of a duty would not serve an interest worthy of protection. More importantly, in the case of P1 the duty-holder would simply not be able to fulfil their duty if the right-holder was not competent of realising the right. All rights necessitate a level of competency on the part of the right-holder, and some rights necessitate that this competence be linked to autonomy.

Interest theory may have shown us that there is no conceptual need for competence in order to qualify as a right-holder. However, the theory necessitates that the right-holder have the competence to realise the right in order for the interest to be of sufficient importance to impose duties and restrict the liberties of others. This assessment is of particular relevance when considering whether children hold rights. The limited and evolving capacities and competencies of children of all ages do not preclude them from being recognised as a person capable of holding rights. However, the evolving competencies of individual children are relevant to the question of which specific rights they hold. Interest theory, thus understood, demonstrates that a child's capacities and competencies are an essential part of their rights claims. Therefore a child only holds a right when they have the competence to realise the benefit to which the claim pertains.

Conceiving of the relationship between capacity, competency and rights in this way lessens the importance of the distinction between child and adult in rights theory. In order to decide whether one can hold rights and which rights they have, it is not crucial to know whether one falls directly into the category of child or adult, but rather what interest, constrained by the competencies, that individual holds. This aligns to recent work on the enfranchisement of the child, as Lopez-Guerra has argued:

A person ought to have the right to vote if she has this capacity in the minimum degree required for voting - that is, to the extent where she can understand what an election is about and complain for not being allowed to participate. (Lopez-Guerra, 2010, p. 21) 
Similarly persons that do not have the required competency to vote, 'cannot suffer the harms of disfranchisement' (2010, p. 20).

The accrual of rights is not linear to the accrual of competencies - for an individual's competencies and interests may fluctuate throughout their life. This may in turn challenge the idea that there exists a static full set of rights for adults. Just as rights change for children as they gain or lose competencies, the same may be true for adults. However, children still present a distinct case from others with reduced competencies, such as the elderly and the mentally incapacitated, for two reasons. First, children are in a unique period of development; they acquire competencies at a rate unparalleled in other stages of life. Because of this rapid change, if we are not clear on exactly how competency interacts with rights, we are in very real danger of disenfranchising those who should be enfranchised. Second, as children are not in a static state of incompetence, unlike the mentally disabled, they may hold rights to develop competencies in the future, which will produce new and different duties. To put children in the same basket as animals, the mentally disabled, or the elderly, as many traditional liberal philosophers have done, is to overlook the differences in their state of being, a grave mistake that may be of detriment to members of all groups.

A clear understanding of these concepts - capacity, competence and rights - and the relationship between them provides us with a clear framework, the necessary tools if you like, in order to properly tackle the contemporary challenges to children's rights, for example how to translate these rights into a legislative regime, or to protect the future interests of the current child. The framework of rights presented above allows us to recognise children as right-holders, but still constrain the particular types of rights they hold according to their competencies.

\section{Conclusion}

Throughout this article I have demonstrated the relationship between capacity, competency and rights, an important project due to the continuing prevalence in rights theory of the argument from incompetence. I have argued that children are capable of holding rights, if we understand rights as Hohfeldian claims that pertain to a duty to either do or to refrain from doing a particular action. The power to enforce this action can be held by the right-holder or by another designated entity. This claim constitutes a right when it is based on an interest worthy of protection. An interest is worthy of protection when the right-holder has the capacity to realise the benefit to which the interest pertains, and the cost of fulfilling the duty is not unreasonable.

Interest theory has successfully removed the conceptual impediments to children being right-holders by determining that it is not necessary to have the capacity to enforce a claim in order to hold a right. However, it has not shown 
that it is unnecessary to have the capacity to realise a claim. I have argued that one's competency to realise the interest to which the claim pertains is necessary for that claim to constitute a right and to justify the cost of the duty imposed on the liberties of others.

Understanding claims in this way allows us to conceive of a theory of children's rights that properly enunciates the relationship between an individual's competencies and their rights. It in turn lessens the importance in rights theory for a clear definition of childhood. Understanding the relationship between competence and rights is necessary for the specific challenges the rights of children present us, such as their rights to develop future competencies.

\section{Acknowledgements}

I thank Tom Campbell, Christian Barry, Keith Dowding, Nicholas Duff and two anonymous reviewers for their comments and suggestions on earlier versions of this article.

\section{Notes}

1 The Australian.

2 For children's status as right-holders see David Archard (2004); Tom Campbell (1992); Neil MacCormick (1976); Onora O’Neill (1988); Laura Purdy (1994).

3 For an interesting discussion on how children have been neglected throughout political theory, see Turner and Matthews (1998).

4 In this section I am indebted to the work of J.C Lau. These distinctions and how they play out in relation to children are further explained and developed in forthcoming work by Cowden and Lau (forthcoming).

5 For will theory the relevant factor is not that cannot simply articulate a choice but that they 'lack the requisite autonomy, in the moral much more importantly than in the merely physical sense of the term' (Goodin and Gibson, 1997, p. 186).

6 Goodin and Gibson do argue that competence is still necessary to interest theory, but for a different reason. They assert that competency in autonomy and the capacity to have plans for the future are integral to the construction of an interest. Even if children cannot articulate these plans, they are easily discernible to the duty-holder (Goodin and Gibson, 1997, p. 195).

7 Singer takes a similar position when stating that a man cannot have a right to have an abortion. 'A stone does not have interests because it cannot suffer. Nothing that we can do to it could possibly make any difference to its welfare. A mouse, on the other hand, does have an interest in not being tormented, because it will suffer if it is' (Singer, 1974).

\section{References}

Archard, D. (2004) Children Rights and Childhood, 2nd edn. Abingdon, UK: Routledge. Aries, P. (1962) Centuries of Childhood. London: Jonathan Cape.

378 (C) 2012 Macmillan Publishers Ltd. 1470-8914 Contemporary Political Theory Vol. 11, 4, 362-380 
Brennan, S. (2002) Children's choices or children's interests: Which do their rights protect? In: D. Archard and C.M. Macleod (eds.), The Moral and Political Status of Children. Oxford: Oxford University Press.

Brighouse, H. (2002) What rights (if any) do children have? In: D. Archard and C.M. Macleod (eds.), The Moral and Political Status of Children. Oxford: Oxford University Press.

Brocklehurst, H. (2006) Who's Afraid of Children? Children, Conflict and International Relations. Aldershot, UK: Ashgate.

Campbell, T. (1992) The rights of the minor: As person, as child, as juvenile, as future adult. International Journal of Law, Policy and the Family 6(1): 1-23.

Cowden, M. (2011) What's love got to do with it? Why a child does not have a right to be loved. Critical Review of International Social and Political Philosophy. Published online 4 August 2011; DOI: $10.1080 / 13698230.2011 .572426$.

Cowden, M. and Lau, J.C. (forthcoming) The Language of Capacity and Competence in Children's Rights.

Dowding, K. (2006) Can capabilities reconcile freedom and equality? Journal of Political Philosophy 14(3): 323-336.

Federle, K.H. (1994) Rights flow downhill. International Journal of Children's Rights 2(3): 343-368.

Fortin, J. (2003) Children's Rights and the Developing Law, 3rd edn. Cambridge: Cambridge University Press.

Goodin, R. and Gibson, D. (1997) Rights, young and old. Oxford Journal of Legal Studies 17(2): $185-203$.

Griffin, J. (2002) Do children have rights. In: D. Archard and C.M. Macleod (eds.), The Moral and Political Status of Children. Oxford: Oxford University Press.

Hart, H.L.A. (1955) Are there any natural rights? Philosophical Review 64(2): 175-191.

Hart, H.L.A. (1982) Essays on Bentham: Studies in Jurisprudence and Political Theory. Oxford: Clarendon Press.

Hobbes, T. (1985) Leviathan, [1651] London: Penguin Books.

Kramer, M. (1998) Rights without trimmings. In: M. Kramer, N.E. Simmonds and H. Steiner (eds.), A Debate over Rights. Oxford: Oxford University Press, pp. 7-111.

Lansdown, G. (2005) The Evolving Capacities of the Child. Italy: Innocenti Insight, United Nations Children's Fund (UNICEF).

Locke, J. (2004) Two Treatises of Government, [1690]. Cambridge: Cambridge University Press.

Lopez-Guerra, C. (2010) Enfranchising minors and the mentally impaired. Paper presented at the Symposium in Honor of Brian Barry. New York: Columbia University.

MacCormick, N. (1976) Children's rights: A test case for theories of right. Archiv fur Rechts- und Sozialphilosophie 62(3): 305-317, reprinted in Legal Right and Social Democracy: Essays in Legal and Political Philosophy [1982]. Oxford: Clarendon Press.

Mill, J. (1992) On Liberty, [1859]. New York: Legal Classics Library.

Morriss, P. (2002) Power: A Philosophical Analysis, 2nd edn. Manchester: Manchester University Press.

O'Neill, O. (1988) Children's rights and children's lives. Ethics 98(3): 445-463.

Piaget, J. (2004) The Construction of Reality in the Child, [1954]. Abingdon, UK: Routledge.

Purdy, L.M. (1994) Why children shouldn't have equal rights. International Journal of Children's Rights 2(3): 223-241.

Raz, J. (1984) The nature of rights. Mind 93(370): 194-214.

Singer, P. (1974) All animals are equal. In: T. Reagan and P. Singer (eds.), Philosophical Exchange. Brockport, NY: The Center for Philosophic Exchange, pp. 103-116.

Steiner, H. (1998) Working rights. In: M. Kramer, N.E. Simmonds and H. Steiner (eds.), A Debate over Rights. Oxford: Oxford University Press, pp. 233-301. 
Sumner, L. (1987) The Moral Foundations of Rights. Oxford: Oxford University Press.

The Australian. http://www.theaustralian.com.au/news/opinion/sixteen-and-too-immature-to-vote/ story-e6frg6zo-1225786800261.

Turner, S.M. and Matthews, G.B. (1998) The Philosopher's Child: Critical Perspectives in the Western Tradition. Rochester, NY: University of Rochester Press.

Veerman, P. (1992) The Rights of the Child and the Changing Image of Childhood. The Netherlands: Martinius Nijhoff.

Wellman, C. (1995) Real Rights. New York: Oxford University Press.

Wenar, L. (2005) The nature of rights. Philosophy and Public Affairs 33(3): 223-252. 